\title{
Interleukin-12 inhibits cell invasion in choriocarcinoma
}

\author{
ZHUO ZHANG, QIAN XU, CHANGHUA SHI and YUHONG LI \\ Department of Basic Medicine, Chengde Medical College, Chengde 067000, Hebei, P.R. China \\ Received January 4, 2012; Accepted February 23, 2012
}

DOI: $10.3892 / \mathrm{ijmm} .2012 .960$

\begin{abstract}
Gestational trophoblastic disease (GTD) is a unique disease that arises from allografting of the conceptus, and has a characteristic morphology and biological behavior. It encompasses a spectrum of interrelated diseases, including hydatidiform mole, invasive mole, choriocarcinoma and placental-site trophoblastic tumor, but its pathogenesis remains unrevealed. Particularly, choriocarcinoma is a highly malignant tumor with poor prognosis. In this study, we cultured the human choriocarcinoma cell line JEG-3 in vitro. After treating the cells with different doses of interleukin (IL)-12, the cell invasion was observed. We also detected the expression of matrix metalloproteinases (MMP)-9 and tissue inhibitors of metalloproteinases (TIMP)- 1 and the cell cycle of JEG-3 cells. Our data indicated that IL-12 inhibits cell invasion in a dose- and time-dependent manner through regulating the expression of MMP-9 and TIMP-1. In addition, treatment with IL-12 redistributes the phases of the cell cycle in JEG-3 cells. These findings suggest an antitumor role of IL-12 in choriocarcinoma, with far reaching possibilities for understanding the mechanisms of IL-12.
\end{abstract}

\section{Introduction}

The GTD is a rare disease that arises from allografting of the conceptus, and characterized by an abnormal proliferation, local invasion and widespread metastasis. It encompasses a spectrum of interrelated diseases, including hydatidiform mole, invasive mole, choriocarcinoma and placental-site trophoblastic tumor (1), but choriocarcinoma is the unique highly malignant tumor originated in mononuclear cytotrophoblasts and multinucleated syncytiotrophoblasts (2). As other tumors, abnormal proliferation and invasion of trophblast cells can lead to the development of choriocarcinoma. Matrix metalloproteases (MMPs) and the tissue inhibitors of metalloproteinases (TIMPs) as important factors related to the degradation of extracellular matrix (ECM), taking part in invasion and metastasis of tumor cells $(3,4)$. However, different

Correspondence to: Professor Yuhong Li, Department of Basic Medicine, Chengde Medical College, Chengde 067000, Hebei, P.R. China

E-mail: youngcheer2003@foxmail.com

Key words: interleukin-12, choriocarcinoma, JEG-3 cell, invasion, matrix metalloprotease-9, tissue inhibitor of metalloprotease-1 from tumor of a host tissue, choriocarcinoma can occur after a pregnancy and during implantation; trophoblastic invasion is strictly regulated temporospatially (5). As a component of germ cell tumors or a poorly differentiated somatic carcinoma with distinct clinical features, choriocarcinoma plays the role of stem cells (6). As the preferred medication, the acquired resistance of 5-fluorouracil is too serious to lead the curative effect of high-risk patients with choriocarcinoma (7). Since conventional treatments including surgery and chemotherapy often fail, novel therapeutic strategies are needed. In particular, cytokine therapy has fostered the progress of immunotherapy. In recent years, the immunoregulatory function and antitumor activity of interleukin(IL)-12 is gradually becoming a research hotspot. Some promising results have been obtained for other tumors (8-10).

The IL-12 is a cytokine that exerts immunoregulatory effects on T cells and NK cells, and is produced by antigen presenting cells, such as macrophages and mononuclear cells. IL-12 was found to be effective for promoting cell-mediated immunity and antitumor effects in mouse tumor models, human tumor tissues, and in cells of a variety of infections diseases (11-14), therefore, it can be used for other tumors, but reports on choriocarcinoma research are scarce. It has been demonstrated that IL-12 inhibited the proliferation and invasion of choriocarcinoma JEG-3 cells only to a small extent in $1,000 \mathrm{pg} / \mathrm{ml}$ and for $48 \mathrm{~h}$ (15), whereas to our knowledge, no studies to date have demonstrated the function of higher doses and longer action times of IL-12. Furthermore, it is necessary to be elucidated because our earlier studies $(16,17)$ have proved that the anti-proliferation of IL-12 was inversely correlated with concentrations in JEG-3 cells with higher doses, this result was not exactly consistent with that of $0-1,000 \mathrm{pg} / \mathrm{ml}$ for $48 \mathrm{~h}(15)$.

Based on these observations, we aimed to investigate the effect of different higher concentrations and different longer action times of IL-12 on cell cycle and invasion in JEG-3 cells, at the same time, we investigated the expressions of MMP-9 and TIMP-1 for possible mechanisms of invasion, to provide theoretical basis for pathogenesis and new insights into clinical early treatment of choriocarcinoma.

\section{Materials and methods}

Materials. JEG-3 cells were purchased from the State Key Laboratory of Reproductive Biology (SKLRB), affiliated to Institute of Zoology (IOZ), Chinese Academy of Sciences (CAS). 
Table I. PCR primers used in reaction.

\begin{tabular}{llcc}
\hline Target & \multicolumn{1}{c}{\begin{tabular}{c}
\multicolumn{1}{c}{ Primer sequences } \\
$\left(5^{\prime} \rightarrow 3^{\prime}\right)$
\end{tabular}} & $\begin{array}{c}\text { Product size } \\
(\mathrm{bp})\end{array}$ & $\begin{array}{c}\text { Annealing } \\
\text { temperature }\left({ }^{\circ} \mathrm{C}\right)\end{array}$ \\
\hline MMP-9 & $\begin{array}{l}\text { F: TCG TGC CTC TGC CCA TAG G } \\
\text { R: CAC CCT TGT GCT CTT CCC TG }\end{array}$ & 463 & 57 \\
TIMP-1 & F: GTT GTT GCT GTG GCT GAT AG & 265 & 58 \\
$\beta$-actin & R: TGT GGG ACC TGT GGA AGT A & & 58 \\
& F: AGC GGG AAA TCG TGC GTG AC & 453 & \\
\hline
\end{tabular}

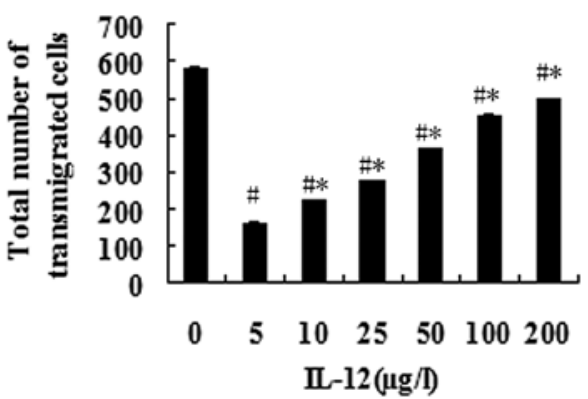

Figure 1. The JEG-3 cells were treated with IL-12 for $48 \mathrm{~h}$, then their invasive capacity was detected using Transwell invasion assay, the total number of transmigrated cells were counted under a light microscope. Exogenous IL-12 specifically inhibited the invasive capacity of JEG-3 cells. The data are presented the mean $\pm \mathrm{SD}\left(\mathrm{n}=5 ;{ }^{*} \mathrm{P}<0.05\right.$ compared with IL-12 $0 \mu \mathrm{g} / 1$; ${ }^{*} \mathrm{P}<0.05$ compared with the other groups, except $0 \mu \mathrm{g} / 1$.

$J E G-3$ cell culture. JEG-3 cells were cultured in an incubator with $5 \% \mathrm{CO}_{2}$ on $37^{\circ} \mathrm{C}$ in Dulbecco's modified Eagle's medium (DMEM) (Gibco-BRL,USA) with 10\% fetal bovine serum (FBS) (Hangzhou Sijiqing Biological Engineering Materials Co., Ltd., China), $100 \mathrm{mM}$ pyruvic acid Na, $200 \mathrm{mM}$ glutatine, $100 \mathrm{U} / \mathrm{ml}$ penicillin and $100 \mu \mathrm{g} / \mathrm{ml}$ streptomycin. Cells were not subcultured with $0.25 \%$ trypsin and $0.02 \%$ EDTA until the cell growth reached $70-80 \%$, and the density of subcultured cells was $1: 2$ to $1: 4$.

Transwell invasion assay. Cell invasion assay was performed using $6.5 \mathrm{~mm}$ transwell inserts with polycarbonate membrane filters containing $8-\mu \mathrm{m}$ pores (Corning Inc., Acton, MA, USA), and then a thin layer of growth factor-reduced diluted Matrigel (BD Biosciences, NJ, USA) (18), was incubated on top of membranes at $37^{\circ} \mathrm{C}$ and the inserts were placed into 24-well culture plates containing $500 \mu 1$ of DMEM supplemented with $20 \%$ FBS. After gel formation, $2 \times 10^{4}$ cells $/ 200 \mu \mathrm{l}$ of serum-free DMEM, respectively, containing $0,5,10,25,50,100,200 \mu \mathrm{g} / 1 \mathrm{IL}-12$ were plated in the upper chambers and cultured for $24 \mathrm{~h}$. Cells from the upper surface of the Matrigel layer were rubbed off gently with cotton swab and then naturally dried, the invading cells attached to the membrane were fixed in $4 \%$ paraformaldehyde for $10 \mathrm{~min}$ and stained with hematoxylin (19). The total number of transmigrated cells were determined by counting the number of dying cells in 10 randomly selected fields of vision at $\mathrm{x} 200$ magnification with a light microscope. Cell invasion was performed on five independent occasions.

Reverse transcription (RT)-PCR. The cells were incubated in 6-well plates with the density of $3 \times 10^{4} / \mathrm{ml}$ and then allowed to grow for $48 \mathrm{~h}$, followed by culture with serum-free DMEM for $24 \mathrm{~h}$. After cell synchronization, different concentrations human recombinant IL-12 were added into each well in the following groups: $0,5,10,25,50,100,200 \mu \mathrm{g} / 1$, and continued incubating for $48 \mathrm{~h}$. Our preliminary experiment demonstrated that $5 \mu \mathrm{g} / \mathrm{l}$ was the most effective stimulative concentration in our experiment range (16). JEG-3 cells were induced with IL-12 $5 \mu \mathrm{g} / \mathrm{l}$ for $24,36,48$ and $72 \mathrm{~h}$, respectively. Total-RNA extraction of JEG-3 cells from each group was isolated with TRIzol reagent (Invitrogen, Carlsbad, CA, USA). RNA was separated by $1 \%$ agarose gel electrophoresis and 28S, 18S, 5S bands were detectable. cDNA was synthesized from $1 \mu \mathrm{g}$ of RNA with oligo(dt)20 primers with the use of the M-MLV first-strand synthesis system kit (Invitrogen). Taq ${ }^{\mathrm{TM}}$ kit (Takara Biotechnology Co., Dalian, Liaoning, China) was used for PCR amplification. Primers used are listed in Table I. $\beta$-actin was the internal control (20). Amplification conditions were as follows: $94^{\circ} \mathrm{C}$ for $2 \mathrm{~min}$, followed by 30 cycles of $94^{\circ} \mathrm{C}$ for $30 \mathrm{sec}$, annealing temperature for $30 \mathrm{sec}$, and $72^{\circ} \mathrm{C}$ for $1 \mathrm{~min}$. PCR product were electrophoresed in 2\% agarose gel and photographed using ZF ultraviolet transmission reflection analyzer (Shanghai Jiapeng Technology, Shanghai, China) and gray values were measured by Quantity One-4.6.2 software (Bio-Rad, Hercules, CA, USA). The relative level of target mRNA expression was defined as the ratio of the absorbance of the target band to $\beta$-actin band.

Western blotting assay. The JEG-3 cells were incubated and then divided into different groups as mentioned above in the method of RT-PCR. Then collected, aschizolysed and centrifuged at $4^{\circ} \mathrm{C}$ and $12,000 \mathrm{r} / \mathrm{min}$ for $20 \mathrm{~min}$. Supernatant was subsequently removed. Protein concentrations were quantified using the Bicinchoninic acid method. Samples were mixed with buffer together at $95^{\circ} \mathrm{C}$ for $10 \mathrm{~min}$, followed by $12 \%$ SDS-PAGE electrophoresis at $80-120 \mathrm{~V}$ for $2 \mathrm{~h}$, and the protein bands were then transferred onto $4 \mathrm{~mA} / \mathrm{cm}^{2} \mathrm{PVDF}$ membrane at $4^{\circ} \mathrm{C}$, blocked with $5 \%$ skim milk. The membranes were incubated with the primary antibody for $2 \mathrm{~h}$, then washed with Tris-buffered saline Tween-20 (TBST) $15 \mathrm{~min}, 10 \mathrm{~min}, 10 \mathrm{~min}$, respectively and incubated with the secondary antibody for $1 \mathrm{~h}$, washed with TBST for $5 \mathrm{~min}$ three times, and then color rendered by Super ECL Plus Luminescence fluid (Applygen 
$\begin{array}{lllllllll}\text { A } & 0 & 5 & 10 & 25 & 50 & 100 & 200 & (\mu \mathrm{g} / \mathrm{l})\end{array}$
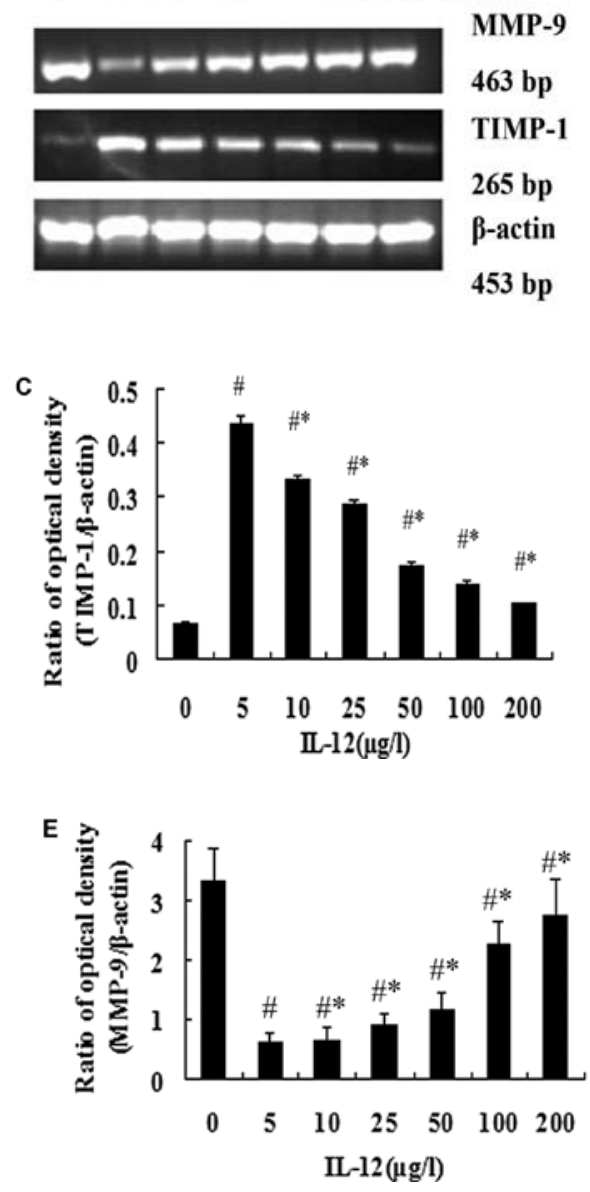
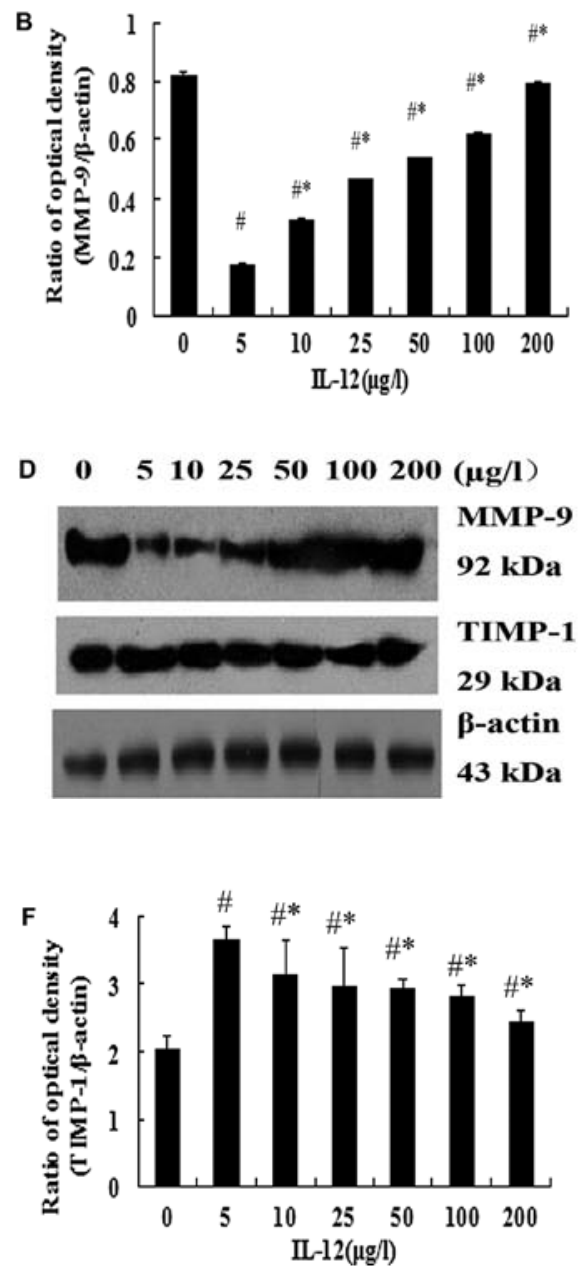

Figure 2. Regulatory effects of different doses with IL-12 on MMP-9 and TIMP-1 mRNA and protein expression levels in JEG-3 cells. (A) RT-PCR analysis of MMP-9 and TIMP-1 mRNA levels in JEG-3 cells cultured in different doses of IL-12, (B and C). Similar analyses followed. (D, E and F) Western blot analysis of MMP-9 and TIMP-1 protein levels. ${ }^{*} \mathrm{P}<0.05$ compared with IL-12 $0 \mu \mathrm{g} / \mathrm{l} ;{ }^{*} \mathrm{P}<0.05$ compared with the other groups, except $0 \mu \mathrm{g} / 1$.

Technologies, Inc., Beijing, China). Images were acquired by scanning, and band gray values were measured by Quantity One-4.6.2 software (Bio-Rad). $\beta$-actin was the internal reference, and relative expression rate of the target protein served as the ratio of the absorbance of the target band to $\beta$-actin band.

Flow cytometry. After the cells were cultured with the density of $3 \times 10^{4} / \mathrm{ml}$ for $48 \mathrm{~h}$, then removed the serum and continued culturing for 24 h. $0,5,10,25,50,100,200 \mu \mathrm{g} / 1 \mathrm{IL}-12$ was added, respectively, to divide the cells into different groups and cultured for 48 and 72 h. The JEG-3 cells were digested, centrifuged and then washed in PBS, fixed in $70 \%$ ethanol at $4^{\circ} \mathrm{C}$ for $24 \mathrm{~h}$. The samples were washed in PBS and centrifuged again, then stained with propidium iodide, incubated in $4^{\circ} \mathrm{C}$ for $30 \mathrm{~min}$. Flow cytometry (Beckman Coulter, USA) diction was performed after the filtration of the samples through 500 screen mesh copper screen.

Statistical analysis. Statistical analysis was performed using SPSS 11.5 software (IBM SPSS Statistics Server, New York, $\mathrm{NY}, \mathrm{USA}$ ). All measurement data were expressed as mean $\pm \mathrm{SD}$, and compared using one-way analysis of variance, following pairwise comparisons of several means between groups were performed using the SNK-q method. A P-value $<0.05$ was considered statistically significant.

\section{Results}

IL-12 restrains the JEG-3 cell invasion. The effect of IL-12 on cell invasion was further assessed (Fig. 1). By transwell invasion assay, compared with $0 \mu \mathrm{g} / \mathrm{l} \mathrm{IL}-12$ group, the transmigrated cells in IL-12 treated groups decreased significantly which indicated reduced invasion $(\mathrm{P}<0.05)$. However, upregulation of IL-12 concentration slowed down the suppression ratio of invasion $(\mathrm{P}<0.05)$. We found that the most effective dose of IL-12 on blocking cell invasion is low dosage of $5 \mu \mathrm{g} / \mathrm{l}$.

Effect of IL-12 on the expression of MMP-9 and TIMP-1 at different doses. MMP-9, TIMP-1 mRNA and protein were determined using RT-PCR and western blotting assay, respectively. The JEG-3 cells were treated with IL-12 for $48 \mathrm{~h}$. Compared with untreated cells, the expressions of MMP-9 mRNA and protein in IL-12-treated groups decreased gradually $(\mathrm{P}<0.05)$, but upregulation of IL-12 concentration increased the expression of MMP-9 (P<0.05) (Fig. 2A, B, D and E). The 

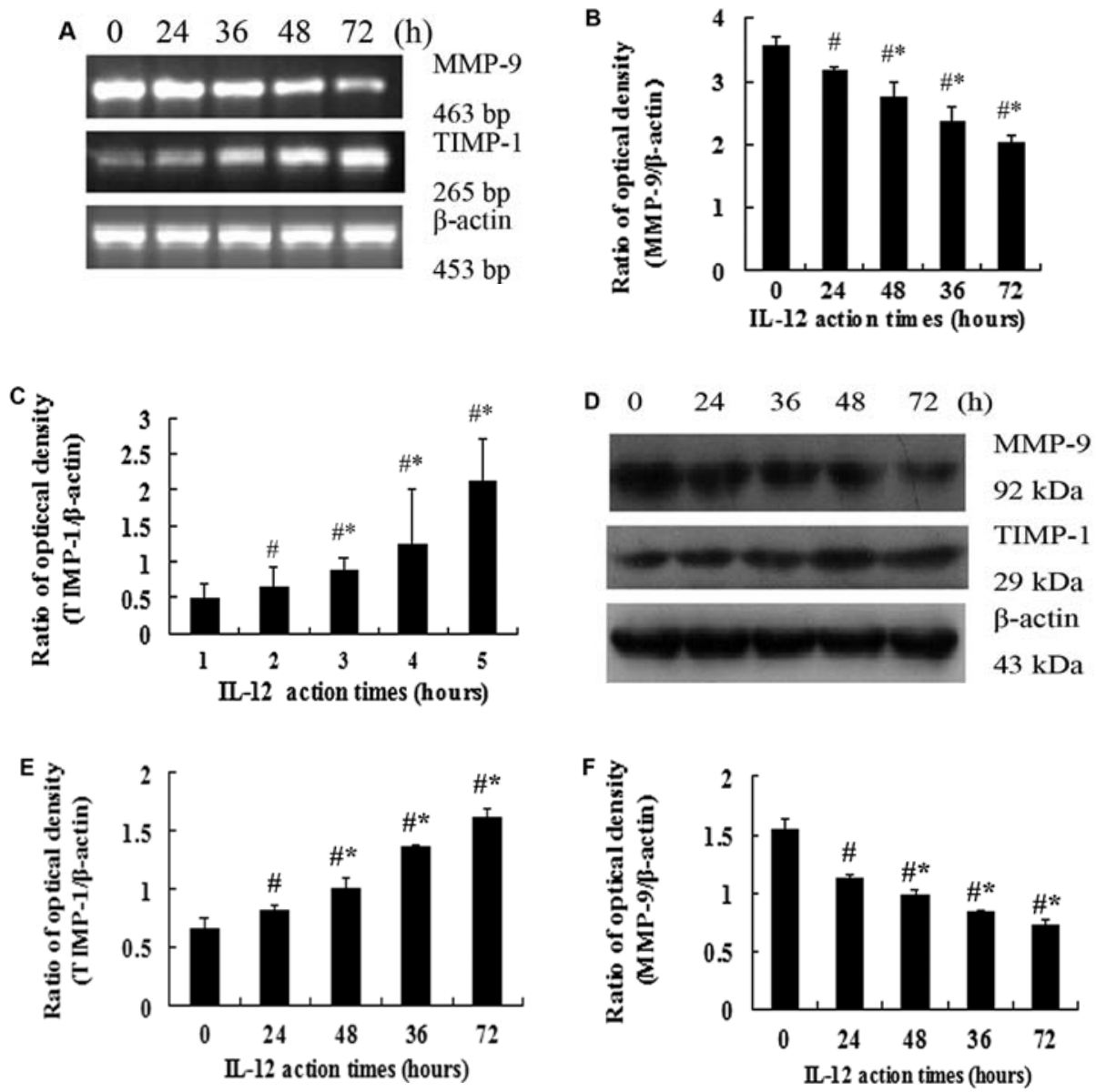

Figure 3. IL-12 downregulated MMP-9 and upregulated TIMP-1 expressions of JEG-3 following extending of IL-12 action times. (A) RT-PCR analysis of MMP-9 and TIMP-1 mRNA expressions at different times of JEG-3 cells. (B and C) The data of MMP-9 and TIMP-1 mRNA expressions. (D, E and F) MMP-9 and TIMP-1 protein expressions and the data by western blot analysis. ${ }^{*} \mathrm{P}<0.05$ compared with $0 \mathrm{~h} ;{ }^{*} \mathrm{P}<0.05$ compared with the other groups, except $0 \mathrm{~h}$.
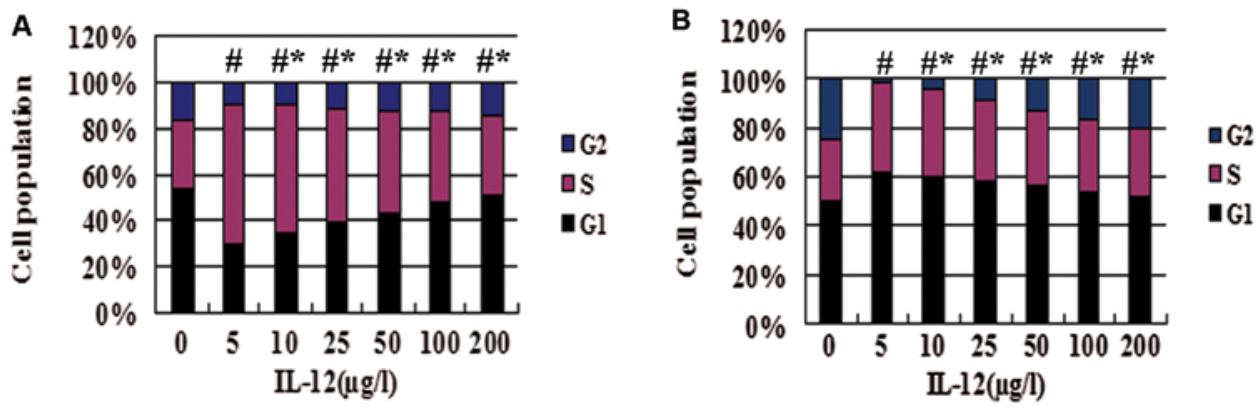

Figure 4 . The cell cycle of JEG-3 cells after incubation with IL-12 for (A) $48 \mathrm{~h}$ and for (B) $72 \mathrm{~h}$ were detected by flow cytometry, both were changed. ${ }^{*} \mathrm{P}<0.05$ compared with $0 \mu \mathrm{g} / 1$, significant differences were observed on $\mathrm{G} 1, \mathrm{~S}, \mathrm{G} 2$; "P<0.05 compared with the other groups, except $0 \mu \mathrm{g} / 1$.

expression of TIMP-1 mRNA and protein in IL-12-treated groups increased $(\mathrm{P}<0.05)$, whereas upregulation of IL-12 concentration decreased the expression of TIMP-1 $(\mathrm{P}<0.05)$ (Fig. 2A, C, D and F).

Effect of IL-12 on the expression of MMP-9 and TIMP-1 at different action times. RT-PCR and western blotting revealed MMP-9 and TIMP-1 mRNA and protein expression on the JEG-3 cells without/with $5 \mu \mathrm{g} / 1 \mathrm{IL}-12$ treatment varied depending on the incubition times. The expression of MMP-9 mRNA and protein were reduced gradually $(\mathrm{P}<0.05)$ (Fig. 3A, B, D and E). On the other hand, TIMP-1 mRNA and protein expression in JEG-3 cells were significant increased following lengthening of the IL-12 action time $(\mathrm{P}<0.05)$ (Fig. 3A, C, D and F).

IL-12 changes the cell cycle of choriocarcinoma cells. Flow cytometry analysis showed that compare it with the blank 
control group ( $0 \mu \mathrm{g} / \mathrm{l})$, the cell cycle of JEG-3 cells in IL-12treated group was obviously arrested, decreased G2 phase cells were founded in both 48 and $72 \mathrm{~h} \mathrm{IL-12}$ treated cells $(\mathrm{P}<0.05)$ (Fig. 4). Cells were arrested in $\mathrm{S}$ phase at both 48 and $72 \mathrm{~h}(\mathrm{P}<0.05)$ (Fig. 4), as well as in $\mathrm{G} 1$ phase at $72 \mathrm{~h}(\mathrm{P}<0.05)$ (Fig. 4B).

\section{Discussion}

Invasion is not only an important biological characteristic of tumors, but also the main factor affecting the cute rate in patients. Through invasion, tumor cells can break the original growing scope and vascular system, continuing to infiltrate the surrounding tissue and enter blood circulation and lymphatic system. Trophoblastic cells act as trophoblast stem cells that differentiate into either syncytiotrophoblasts or villous intermesiated trophoblasts in the process of embryo implantation and placenta formation (21). This distinct histological characteristic may lead trophoblast invasion to differ largely from other tumors, and has its stringent regulation and spatio-temporal restriction, controlled punctually by a complex network system, which is performed by cytokines, growth factors, angiogenesis factors, proteases, and apoptosis regulatory factors.

In this study, we found significantly higher anti-invasion function of IL-12 in JEG-3 cells suggesting that IL-12 may participate in the development of choriocarcinoma. Our observations concur with the role of IL-12 in other malignancies (22-24). Such an anti-invasion ability of IL-12 in JEG-3 cell is not surprising since it has been reported that $<1,000 \mathrm{pg} /$ $\mathrm{ml}$ dose of IL-12 inhibited the invasion of JEG-3 cells and showed dose-dependent effect with the concentration of IL-12 increasing, the JEG-3 cell invasion was obviously weaken (15). On the contrary, the present study found that when the dose of IL-12 exceeded $5 \mu \mathrm{g} / 1$, the dose-dependent effect of IL-12 changed. The more dose of IL-12 increased, the stronger the JEG-3 cells invasion ability was, but still lower than normal. Therefore, IL-12 only showed antitumor effect at a stable dose in this study, and there was no evidence suggesting a higher dose. To the best of our knowledge, this is the first report demonstrating such a different antitumor effect of IL-12 with low and high dose on cancer cells. Our findings suggested that IL-12 may be executing its functional roles differently at different dose and environments.

Some animal experiments and clinical research also manifested that a novel alloimmune involving T helper (Th)1type and Th2-type immunity was important to trophoblast invasion (25-28). In response to trophoblast invasion, myrid of antigen presenting cells and other immune response cells may become activated, a by-product of this activation is the secretion of either a predominant Th1 or Th2 cytokine profile, such as IL-12, and then the balance of Th1 and Th2 is broken, thereby promoting or restraining the development of the tumor. Possibly this is a reason for the antitumor functional role of IL-12. Furthermore, IL-12 indirectly mediated antitumor effects also due to its capability of activating other cell types, such as natural killer T (NKT) cells and natural killer (NK) cells, NKT cells were activated preferentially with low dose of IL-12, but high dose of IL-12 activated NK cells first (29-31) and further reduced its antitumor effect through inducing the number of NKT cells rapidly (32). Involvement of IL-12 at different doses in melanoma producing contrasting effects has been reported (33). Thus, in vivo or in vitro, IL-12 may act through many different pathways to produce various biological effects in the development of cancer.

In the choriocarcinoma cell line, we further found that the cell-invasion effect of IL-12 was likely to be mediated through the downregulation of MMP-9 and upregulation of TIMP-1, which are essential for choriocarcinoma cell invasion (34). The MMP family is an important enzyme degrading extracellular matrix, and the TIMP family is a natural inhibitor of MMP. The imbalance of MMPs and TIMPs in the extracellular matrix has been confirmed to relate with a variety of pathological states, especially tumor invasions and metastasis (35-37). Our recent study revealed that MMP-9/TIMP-1 respond to exogenous IL-12 in JEG-3 cells, in a dose- and time-dependent manner, the expression of TIMP-1 increased. IL-12 can promote the expressions of TIMP-1 to inhibit MMP-9, the balance of MMP-9 and TIMP-1 was broken. These observations were consistent with the invasion assay. Our findings are in agreement with reports by several authors on a similar antitumor role of IL-12 mediated by inhibition of the MMPs and promotion of the TIMPs. Based upon the above and previous findings that exogenous IL-12 can inhibit the proliferation of JEG-3 cells $(16,17)$, we conclude that the antitumor role of IL-12 is not only due to its anti-proliferation ability but also dependent the anti-invasion function.

Moreover, to explore the mechanism of IL-12 in choriocarcinoma, we have adopted flow cytometry to observe the cell cycle in JEG-3 cells after incubation with different doses of IL-12.The anti-proliferation and anti-invasion effects of IL-12 on JEG-3 are probably through the cell arrested at $\mathrm{S}$, or S and G1 phases. The change of cell cycle is found to be essential for restraining the proliferation and reducing the invasion of both human and mouse cancer cells in the development of tumor (38-42). We also demonstrated similar results of IL-12 in JEG-3 cells in this study. IL-12 can affect DNA synthesis of the cells, change the cell cycle and signaling pathways and then make the growth of the JEG-3 cells to arrest at $S$ phase after treatment for $48 \mathrm{~h}$, but after $72 \mathrm{~h}, \mathrm{G} 1$ and S phases were both arrested. In the regulation of cell generation cycle, G0/G1 check point plays an influential role. The regulator through their positive and negative role in regulating cellular DNA synthesis in S phase, induce cells to arrest in G0/G1 phase to inhibit tumor growth. When the IL-12 action after $48 \mathrm{~h}$ was continue, it was found that G1 phase was also arrested and then further affected the proliferation and invasion of the cells.

In summary, our findings suggest an important role of IL-12 in tumor cells, IL-12 can inhibit the proliferation and invasion of JEG-3 cells mediated through the regulation of MMP-9 and TIMP-1 and change the cell cycle. Futhermore, IL-12 exerts various effects between low and high dose, this is the first study to demonstrate a likely role for IL-12 in choriocarcinoma by in vitro experiments, but the exact mechanism remains controversial. In addition, IL-12 has shown considerable toxicity (43), therefore, how to correctly exert the antitumor function of IL-12 and reduce the toxicity also needs to be elucidated by more studies. Such findings may assist to provide the basis for the clinical treatment of choriocarcinoma. 


\section{References}

1. Genest DR, Berkowitz RS and Fisher RA: Gestational trophoblastic disease. In: World Health Organization Classification of Tumours, Pathology and Genetics Tumours of the Breast and Female Genital Organs. Tavassoli FA and Devilee P (eds). IARC Press, Lyon, pp250-254, 2003.

2. Alifrangis $\mathrm{C}$ and Seckl MJ: Genetics of gestational trophoblastic neoplasia: an update for the clinician. Future Oncol 6: 1915-1923, 2010.

3. Decock J, Thirkettle S, Wagtaff L and Edwards DR: Matrix metalloproteinases: protective roles in cancer. J Cell Mol Med 15: 1254-1265, 2011 .

4. Bourboulia D and Stetler-Stevenson WG: Matrix metalloproteinases (MMPs) and tissue inhibitors of metalloproteinases (TIMPs): Positive and negative regulators in tumor cell adhesion Semin Cancer Biol 20: 161-168, 2010.

5. Shih leM and Kuo KT: Power of the eternal youth: Nanog expression in the gestational choriocarcinoma. Am J Pathol 173: 911-914, 2008

6. Cheung AN, Zhang HJ, Xue WC and Siu MK: Pathogenesis of choriocarcinoma: clinical, genetic and stem cell perspectives. Future Oncol 5: 217-231, 2009.

7. van Trommel NE, Lybol C, Thomas CM, Sweep FC and Massuger LF: Diagnosis and treatment of gestational trophoblastic disease. Eur Obstet Gynaecol 6: 28-32, 2011

8. Harden JL, Gu T, Kilinc MO, Rowswell-Turner RB, Virtuoso LP and Eqilmez NK: Dichotomous effects of IFN- $\gamma$ on dendritic cell function determine the extent of IL-12-driven antitumor T cell immunity. J Immunol 187: 126-132, 2011.

9. Simpson-Abelson MR, Purohit VS, Pang WM, et al: IL-12 delivered intratumorally by multilamellar liposomes reactivates memory $\mathrm{T}$ cell in human tumor microenvironments. Clin Immunol 132: 71-82, 2009.

10. Steding CE, Wu ST, Zhang Y, Jeng MH, Elzey BD and Kao C: The role of interleukin-12 on modulating myeloid-derived suppressor cells, increasing overall survival and reducing metastasis. Immunology 133: 221-238, 2011

11. Uemura A, Takehara T, Miyagi T, et al: Natural killer cell is a major producer of interferon gamma that is critical for the IL-12induced antitumor effect in mice. Cancer Immunol Immunother 59: 453-463, 2010

12. Lin BL, Xie DY, Xie JQ, Zhang XH, Mei YY and Gao ZL: Study on HBV antigents and IL-12 affecting T cell-mediated immunity in HBsAg carriers. Zhonghua Gan Zang Bing Za Zhi 19: 186-190, 2011 (In Chinese)

13. Zhang Y, Ma CJ, Ni L, et al: Cross-talk between programmed death-1 and suppressor of cytokine signaling-1 in inhibition of IL-12 production by monocytes/macrophages in hepatitis $\mathrm{C}$ virus infection. J Immunol 186: 3093-3103, 2011.

14. Villinger F and Ansari AA: Role of IL-12 in HIV infection and vaccine. Eur Cytokine Netw 21: 215-218, 2010.

15. Karmakar S, Dhar R and Das C: Inhibition of cytroblastic (JEG-3) cell invasion by interleukin 12 involves an interferon- $\gamma$ mediated pathway. J Biol Chem 279: 55297-55307, 2004.

16. Zhang Z, Li YH and Xu Q: Effect of different concentrations of interleukin-12 on proliferation in JEG-3. J Clin Exp Med 10: 161-164, 2011.

17. Zhang Z, Li $\mathrm{YH}$ and $\mathrm{Xu} \mathrm{Q}$ : The effect of recombinant human IL-12 on cytoactive in vitro choriocarcinoma cell. Hebei Med 17: $572-574,2011$

18. Beristain AG, Zhu $\mathrm{H}$ and Leung PC: Regulated expression of ADAMTS-12 in human trophoblastic cells: a role for ADAMTS-12 in epithelical cell invasion? PLoS One 6: e18473, 2011.

19. Nicolson GL: Transfilter Cell Invasion Assays. In: Cell biology: a laboratory handbook. Celis JE (ed). Vol. 1. Academic Press, New York, pp359-362, 2006.

20. Suzuki T, Higgins PJ and Crawford DR: Control selection for RNA quantitation. Biotechniques 29: 332-337, 2000.

21. Siu MK, Wong ES, Chan HY, Ngan HY, Chan KY and Cheung AN: Overexpression of Nanog in gestational trophoblastic disease-effect on apoptosis, cell invasion, and clinical outcome. Am J Pathol 173: 1165-1172, 2008.

22. Ye ZB, Ma T, Li H, Jin XL and Xu HM: Expression and significance of intratumoral interleukin-12 and interleukin-18 in human gastric carcinoma. World J Gastroenterol 13: 1747-1751, 2007.
23. Komita H, Homma S, Saotome H, Zeniya M, Ohno T and Toda G Interferon-gamma produced by interleukin-12-activated tumor infiltrating $\mathrm{CD} 8^{+} \mathrm{T}$ cells directly induces apoptosis of mouse hepatocellular carcinoma. J Hepatol 45: 662-672, 2006.

24. Du LJ, Zhang HY, Liu J, Sun YN, Chen X and Liu M: Effection of IL-12 and TFPI-2 transfected in invasion and apoptosis of laryngeal squamous carcinoma. Chin J Prim Med Pharm 17: 299-300, 2010

25. Hill JA III and Choi BC: Immunodystrophism: evidence for a novel alloimmune hypothesis for recurrent pregnancy loss involving Th1-type immunity to trophoblast. Semin Reprod Med 18: 401-405, 2000

26. Vilches $\mathrm{C}$ and Parham P: KIR: diverse, rapidly evolving receptors of innate and adaptive immunity. Annu Rev Immunol 20: 217-251, 2002.

27. Arriage-Pizano L, Jimenez-Zamudio L, Vadillo-Ortega F, MartinezFlores A, Herrerias-Canedo $\mathrm{T}$ and Hernandez-Guerrero C: The predominant Th1 cytokine profile in maternal plasma of preeclamptic women is not reflected in the choriodecidual and fetal compartments. J Soc Gynecol Investig 12: 335-342, 2005.

28. Saito S and Sakai M: Th1/Th2 balance in preeclampsia. J Reprod Immunol 59: 161-173, 2003

29. Cui J, Shin T, Kanano T, et al: Requirement for valpha 14 NKT cells in IL-12-mediated rejection of tumors. Science 278: 1623-1626, 1997.

30. Zhu R, Diem S, Araujo LM, et al: The pro-Th1 cytokine IL-12 enhances IL-4 production by invariant NKT cells: relevance for T cell-mediated hepatitis. J Immunol 178: 5435-5442, 2007.

31. Smyth MJ, Crowe NY, Hayakawa Y, Takeda K, Yaqita H and Godfrey DI: NKT cells - conductors of tumor immunity? Curr Opin Immunol 14: 165-171, 2002.

32. Eberl G and MacDonald HR: Rapid death and regeneration of NKT cells in anti-CD3epsion-or IL-12-treated mice: a major role for bone marrow in NKT cell homeostasis. Immunity 9: 345-353, 1998.

33. Leonard JP, Sherman ML, Fisher GL, et al: Effects of single-dose interleukin-12 exposure on interleukin-12 associated toxicity and interferon-gamma production. Blood 90: 2541-2548, 1997.

34. Singh M, Kindelberger D, Nagymanyoki Z, et al: Matrix metalloproteinases and their inhibitors and inducer in gestational trophoblastic diseases and normal placenta. Gynecol Oncol 122: 178-182, 2011.

35. Zarrabi K, Dufour A, Li J, et al: Inhibition of matrix metalloproteinase 14 (MMP-14)-mediated cancer cell migration. J Biol Chem 286: 33167-33177, 2011.

36. Kang H, Jang SW and Ko J: Human leucine zipper protein sLZIP induces migration and invasion of cervical cancer cells via expression of matrix metalloproteinase-9. J Biol Chem 286: 42072-42081, 2011.

37. Singh RD, Haridas N, Patel JB, Shah FD, Shukla SN, Shah PM and Patel PS: Matrix metalloproteinases and their inhibitors: correlation with invasion and metastasis in oral cancer. Indian $\mathrm{J}$ Clin Biochem 25: 250-259, 2010.

38. Wang KY, Xiong AZ, Jiang XX, Li L, Li HZ and Fu HQ: Cyclindependent kinase inhibitor roscovitine suppresses the invasion of human hepatocellular carcinoma SMMC-7721 cells in vitro. World Chin J Digestol 18: 119-124, 2010.

39. Deng YT and Lin JK: EGCG inhibits the invasion of highly invasive CL1-5 lung cancer cells through suppressing MMP-2 expression via JNK signaling and induces G2/M arrest. J Aqric Food Chem 59: 13318-13327, 2011.

40. Song B, Song WG, Li ZJ, Xu ZF, Wang XW, Wang CX and Liu J: Effect of HMGB1 silencing on cell proliferation, invasion and apoptosis of MGC-803 gastric cancer cells. Cell Biochem Funct: Sep 27, 2011 (Epub ahead of print).

41. Kim HJ, Kim JC, Min JS, et al: Aqueous extract of Tribulus terrestris Linn induces cell growth arrest and apoptosis by downregulating NF- $\mathrm{KB}$ signaling in liver cancer cells.J Ethnopharmacol 136: 197-203, 2011 .

42. Caers J, Menu E, De Raeve H, et al: Antitumor and antiangiogenic effects of Aplindin in the 5TMM syngeneic models of multiple myeloma. Br J Cancer 98: 1966-1974, 2008.

43. Cocco C, Postoia V and Airoldi I: New perspectives for melanoma immunotherapy: role of IL-12. Curr Mol Med 9: 459-469, 2009. 